\title{
The Model of Development Therapeutic Speech in the Digital Era: A Study of "Interpretation of Al- Mishbah" for Cyber-Counseling Services
}

\author{
A Samsul ${ }^{1}, \mathrm{Nawawi}^{2}$, A F Risma ${ }^{3}$ \\ Ibrahimy University, Situbondo, Indonesia ${ }^{1,2,3}$ \\ \{syamsulahasan@ibrahimy.ac.id ${ }^{1}$, nawawi@ibrahimy.ac.id ${ }^{2}$, rismafahrulamin@ibrahimy.ac.id $\left.{ }^{3}\right\}$
}

\begin{abstract}
In the digital era, counseling services are required to use internet technology media or cyber-counseling. This paper is aimed to develop therapeutic speech principles in Tafsir Al-Mishbah by M. Quraish Shihab and their implementation on cyber-counseling communication skills for Indonesian culture. This study uses a hermeneutic type of qualitative method. Therapeutic speech principles in Al-Qur'an includes1) qaulan baligha, which means a good speech, concise and easy to understand. 2) qaulan ma'rufa means kind, honorable and received by values prevailing in the society. 3) qaulan sadidan, means the truth speech, right and bright. 4) qaulan kariman means noble, gentle, generous speech and respect. 5) qaulan layyinan, means soft and polite speech. 6) qaulan maysuran means is the speech that triggers positivism and positive vibes. These six principles can be applied to cyber-counseling communication skills; on attending skills, listening skills, and influencing skills. In its implementation, it must maintain a balance between verbal and non-verbal speech, between the personality qualities of the counselor and the high desire of the counselee; so that both hearts are united (congruence), which can be seen from the texts in the counseling process that show how warm their self-disclosure is.
\end{abstract}

Keywords: Therapeutic Speech, Communication Skills, Cyber-counseling

\section{Introduction}

In the life of the Muslims, Al-Qur'an and its interpretations play an important role. AlQur'an relates to its existence and function as the main source and guidance (hudan li an-nas) which is the most authoritative. The importance of tafsir relates to the purpose and benefits as a kind of guidebook that is operational-applicative as well as a way to deliver true life [1]. Tafsir of Al-Qur'an is an interpretation of the purpose of the verses of Al-Qur'an according to human abilities. The ability of humans to interpret Al-Qur'an have differences and multilevel according to the interpreter's social and cultural background, and the progress of science. Mufassirs are required to explain the values in Al-Qur'an according to the development of society so that Al-Qur'an can truly function as a guide, separating truth and falsehood, and offering solutions to life's problems [2].

Some academics have tried to review "thematic tafsir" about communication verses in AlQur'an, for example, the roots of communication in Al-Qur'an [3] communication ethics in 
Islamic studies, both Al-Qur'an and Hadith [4] as for those who associate the verses of communication with concrete examples [5] verses of communication with da'wah ethics [6] and communication ethics in Al-Qur'an and its implementation in character education [7]. There is also a paper that discusses counseling communication skills associated with the verse Al-Qur'an in Sufistic counseling services to reach al-maqamat and al-ahwal [8]. But there is no written "tafsir" of the principles of communication that relate to counseling communication skills.

The basic skills of counseling communication are very important in counseling because counseling is essentially the art of communicating. For the counselor, the art of communication is how to collect data relating to the potentials and problems of the counselee, and then be able to turn it into a person who grows and develops better. For the counselee, the art of communication is how to convey all the data and problems themselves. Therefore, the communication skills used by these counselors include the determinants of success in counseling relationships [9].

Counseling includes applied and interdisciplinary sciences. As an interdisciplinary science, in implementing it, counseling requires sociology, anthropology, philosophy, theology, and art [10]. As an applied science, counseling is a practice that develops as a response to the social conditions and the results of the creativity of its practitioners [10]. As an applied science, counseling also develops according to the demands of the user's age.

In this millennial era, counseling is also required to use internet technology media or cyber-counseling. Why is cyber-counseling? First, face to face counseling services is less attractive to students. The results of Nur Hidayah's [11] study in Malang showed that junior high school students who used counseling services were only $15 \%$. So, it happened in SMA / SMK / MAN and Universities. Second, the number of counselors is limited. According to the survey results of the implementation of counseling services in East Java, counselors are very limited; out of balance by the number of students who receive counseling guidance. Therefore, face to face counseling services is being abandoned by students [12]. Third, the millennial era, young people are already familiar with social media such as Facebook, Twitter, Instagram, blogs, e-mail, Skype, WhatsApp, and video call. Social media can be an important means to be maximized and become an option for students to consult their problems.

Cyber-counseling also has advantages. Using cyber-counseling services, counselees feel more comfortable and safer. Cyber-counseling is also not fastened by distance and time. Counseling can be done anywhere and anytime, provided there is an internet network [13], [14]. Zack [15] classifies cyber-counseling services into four types. First, telephone counseling. Second, broadcast counseling. Third, email counseling. Fourth, video-conference counseling.

This paper aims to describe the therapeutic speech principles in the Tafsir of Al-Mishbah: Message, Impression, and Harmony of Al-Qur'an by M. Quraish Shihab and the implementation of these therapeutic speech principles in counseling communication skills for Indonesian culture, especially in the context of cyber-counseling. The selection of tafsir by Quraish Shihab is because he is one of the leading Indonesian commentators and has knowledge of Indonesian social culture. So that this paper is expected to enrich our horizons and can be applied in counseling practices that are extracted from the values of Al-Qur'an based on Indonesian culture.

\section{Method}

This study use as hermeneutic type of qualitative research method. The hermeneutic approach used in this study is adopted from Gadamer's hermeneutics [16]. The hermeneutic 
approach was used to examine the texts related to therapeutic speech in the book Tafsir of AlMishbah: Message, Impression, and Harmony of Al-Qur'an by M. Quraish Shihab to improve counseling communication skills. The steps of this research include: First, the tafsir of parts (parts) by reading small parts of Tafsir Al-Mishbah related to therapeutic speech. Second, the whole tafsir, which arranged the parts relating to therapeutic speech, became a complete meaning. At this stage, the researcher conducted a dialogue by paying attention to its historical context along with prejudice (tradition, practical interests, language, and culture) in interpreting Tafsir Al-Mishbah text related to therapeutic speech and cyber-counseling. Third, understanding basic meaning (understanding of underlying meaning); that is to carry out continuous dialogue by paying attention to himself and parts of the text until a basic understanding occurs [17].

\section{Result and Discussion}

The term qaul or speech has a very broad meaning, either relates to good or bad In Islam, we are commanded to speak well to gets benefits and kept silent to be safe. Therapeutic speech principles in Al-Qur'an include:

\section{Qaulan baligha, interpreted as a good, sufficient and effective speech.}

The term qaulan baligha is found in Surah An-Nisa': 63. According to Shihab, this verse contains the command to turn away from hypocrites by ignoring and not believing their words. We must leave them with forgiveness because Allah will reward them. It also contains commands to give lessons to them using a good speech so they understand well.

The term balighan contains the meaning of the arrival of something to something else or enough (because sufficiency means the arrival of something to the intended limit). Message criteria are called baligh, among others: the sentence must contain all the ideas to be conveyed, the sentence is effective (sufficient; concise and solid), the sentence is easy to understand since it is a match between the content and style of the communicant and conformity with grammar.

According to Shihab, the verse is likened to the heart, as the sentence fi anfusihim, as a recitation container. Because of that, it must be according to the conditions of the container. There is a soul that must be addressed with subtle messages, but there are also souls that need to be honed with loud messages. Thus, we also pay attention to the way the message is delivered and the situation and conditions are not just the words we will convey. Another understanding of the term anfusihim is about themselves; concerning their secrets, so they are aware of their mistakes. It also means conveying lessons to the hypocrites in secret; do not embarrass them explicitly in public [18].

Thus, qaulan baligha also means the speech of the verbal message conveyed by the communicator must be good, sufficient (short and solid), and easy to understand. Besides, it must also pay attention to nonverbal language (for example, kinesthetic, paralingic, proxemic, olfaction, and artifactual). If the verbal and nonverbal languages are fulfilled, then the messages will remain in the heart of the communicant.

\section{Qaulan ma'rufameans kind, honorable and received by values prevailing in society.}

The term qaulan ma'rufa is found in Surah Al-Baqarah: 235 and 263, Surah Al-Ahzab: 32, Surah An-Nisa: 5 and 8. In the context of Surah Al-Baqarah verse 235, Allah does not forbid 
men to say anything to women who are in iddah times. According to Shihab, if you want to say anything to them; say words that are polite and respectful, according to the guidance of religion, which is a good satire [18].

The context of Surah An-Nisa 8, about the suggestion to give charity to those present (relatives, orphans and the poor) in the distribution of inheritance, and say good words; that can comfort their hearts (because of the little charity given or even because nothing will be given).

The context of Surah Al-Ahzab verse 32 contains the position and primacy of the wives of the Prophet Muhammad compared to other women. Allah forbade the wives of the Prophet to be too gentle and soft, made in speech, especially with those who are not muhrim so that bad desires and attract the attention of people who have diseases and impurities in their hearts. But say in good words and in a natural way, not artificial.

According to Shihab, the term qaulan ma'rufa, is a series of sentences that are well by the traditions of the surrounding community, as long as they do not conflict with divine [18]. The word ma'rufan also includes how to pronounce, the sentences spoken, and the style of speech that is not contrived [18].

Thus,qaulan ma'rufa is defined as a good, honorable, by the politeness of the surrounding community. In speaking, we must pay attention to the non-verbal messages, the psychology of the communicant's condition, and the sociology of the surrounding community.

\section{Qaulan sadidan, means the truth, accurate and enlightening speech.}

The term qaulan sadidan is found in Surah An-Nisa: 9 and Surah Al-Ahzab verses 70-71. The context ofSurahAn-Nisa verse 9, the condition of orphans is essentially different from biological children, and this makes them more sensitive that we should be more careful and choose correct sentences. For example, if we reprimand them, we should use reprimands that correct their mistakes, foster and not offend them. Whereas the context of Surah Al-Ahzab verses 70-71, according to Shihab, after Allah forbade lying and false accusations, then Allah commanded the believers to say the right on target.

According to Quraish Shihab, the word sadidan shows the understanding of breaking things down and fixing them; istiqomah; right on target; and enlighten (educate). If we criticize, the criticism must be good, true, constructive, and educational [18].

Thus, sadness and recitation mean true, accurate, consistent and enlightening (educating) words that make us better. The correct, appropriate, and educational speech will affect both us and others.

\section{Qaulan karimanis a noble speech}

The term qaulan kariman contains Surah Al-Isra ': 23. According to Shihab, this group of verses contains the rules of social ethics and reciprocity. We must respect our parents. We should never say ' $a h^{\prime}$ ' or sounds and words that mean anger, abuse, or nausea. We are also prohibited from shouting about anything they do. We are commanded to say noble words that are good, gentle, and full of kindness and respect.

According to Shihab, the word kariman is usually translated as noble. This word consists of letters $\mathrm{kaf}$, $\mathrm{ra}$, and $\mathrm{mim}$ according to language experts contain noble or best meaning according to the object. If it is said rizqun karim, that means halal sustenance in the 
acquisition and utilization and satisfying in the quality and quantity. The word karim is associated with morality facing other people, he means forgiveness [18].

Thus,qaulan kariman, namely noble speech, contains the meaning of words that are good, gentle, and full of kindness, forgiveness (generous) and respect.

\section{Qaulan layyinan, is a soft speech.}

The term qaulan layyinan is found in Surah Thaha: 44. The context of the verse contains the presentation of Prophet Musa and Harun to preach to Fir'aun. Prophet Musa was instructed to speak softly; Prophet Musa was told to invite the Fir'aun to believe in Allah and the truth by not containing antipathy or anger. That way, so that Fir'aun will remember the greatness of Allah and the weakness of the creature so that he is always amazed and obedient to Allah or at least he is always afraid of Allah due to his iniquity.

According to Shihab, qaulan layyinan is a wise attitude and polite speech that does not hurt the target of da'wah. Fir'aun must also be dealt with gently. Indeed, da'wah is a gentle invitation. Da'wah is an effort to convey guidance. The word hidayah which consists of the letters $h a$, dal, and ya means conveying meekly. [18]Thus, qaulun layyin means soft and polite speech which is not an expression of hateful cursing and must be supported by non-verbal messages.

\section{Qaulan maysuranis the speech that triggers positivism and positive vibes.}

The term qaulan maysuran is found in Surah Al-Isra': 28. Some scholars say, the context of this verse comes down when the Prophet Muhammad or the Muslims avoid those who ask for help because they feel ashamed cannot help them. Allah gives guidance through this verse to face them with good words, which does not offend him, and which triggers optimism and positive vibe [18].

Thus, qaulan maysuranis the speech that triggers positivism and positive vibes.

\section{Enhancing Therapeutic Communication Capabilities}

There are several differences among counseling experts about the occurrence of therapeutics. They depend on the theoretical approach. For humanists (for example personcentered therapy counseling), therapeutic change occurs when there is self-disclosure in the context of a trustworthy relationship between counselor and counselee. That is an emphasis on the quality of relationships as core conditions, involved in congruent, empathy, and unconditional acceptance. Therefore, the quality of communication relationships in counseling plays an important role in the occurrence of therapeutics [19]-[21].

The quality of the relationship between counselors and counselees is a necessity for the effectiveness of counseling for behavioral groups. The main focus is not on the quality of the relationship but the intervention process. The main objective of behavioral counseling is to change the performance of counselees in real-life social situations every day through structured training or intervention. Thus, therapeutic relationships are collaborative between counselors and counselees. [10], [21], [22](Mennuti, et. L., 2006: 10-11; Corey, G, 2009: 241-46; McLeod, 2003).

In the context of at-tawazun counseling-counseling that the author explores from the values of pesantren - therapeutic relationships occur when there is a balance (at-tawazun) between the quality of the counselor's personality and the high desire of the counselee. Those 
must be connected, the heart and attitude between counselors and counselees [23], [24] In the context of cyber-counseling by e-mail or chat, the connectedness of heart among counselorscounselees can be seen from the texts in the counseling process that show how warm is their self-disclosure.

To develop the counselor's communication skills, therapeutic words in the interpretation of Al-Mishbah need to be developed. In the view of Quraish Shihab, the six speech principles in Al-Qur'an are not just verbal utterances but must also be supported by non-verbal. For example, the term qaulun ma'rufa, is not just a good verbal utterance but also followed by polite non-verbal messages, according to the traditions of the local community. Because, the principles of communication, among others, consist of dimensions of content that are encoded with verbal messages and dimensions of relationships that are indicated by nonverbal messages [25]

Ivey et [26] explained some communication skills that the counselor must-have. First is listening skills and attending skills. These skills are basic and important because they allow the counselee to continue to talk and explore themselves. In the context of cyber-counseling through tele-talk, we can "see" the counselee through the tone and tone of his voice. In cybercounseling via email or chat, we can "see" the counselee of the texts he wrote and the style of his language [27]. Whereas in cyber-counseling through video conference, we must pay attention to eye contact, tone and vocal qualities, verbal tracking, and body language. Through eye contact, the counselor can grasp the deeper meaning of the various things the counselee tells him. Eye contact also helps the counselee to describe how safe he is with the counselor [26]. In this skill, the counselor can use the principles of communication qaulan ma'rufa, qaulan kariman, and qaulan layyinan.

Second, listening skills to counselee is opening communication (questioning or leading), observation skills, active listening skills: encouraging, paraphrasing, and summarizing, as well as the skills of observing and reflecting feelings [26]. In these listening skills, we can apply the six principles of therapeutic speech.

In the context of cyber-counseling via chat counselors listen to counselees, through writings. The counselor must also pay attention to some of the symbols included in these texts. For example, photos, emotional symbols, font forms, or poems to express their thoughts and feelings [28]. From the results of the research, these skills include those that often occur in cyber-counseling [29]

Third, the skills to help counselees lead to influential actions or skills,involved of confrontation skills, the concentration of interviews, the reflection of meaning, and behavioral change strategies: self-disclosure, feedback, logical consequences, information and psychoeducation, and directive [26]. This skill is also very important because it is an important skill in cyber-counseling [29]

Communication skills, especially verbal language, are derived from the personality integrity of the counselor, because language shows the nation. Language as a means of communication is a reflection of the mind and user of that language [30]Verbal language is the main means to express our ideas, feelings, and intentions. Verbal language represents our reality; describes thoughts, inner experiences, and needs of the wearer. [25]. In short, therapeutic speech, in counseling, is formed and directed subtly by the counselor [10], [31].

Thus, therapeutic speech principles in the interpretation of Al-Mishbah by M. Quraish Shihab can be implemented properly, by counselors who have a good quality of personality integrity. The quality of the shahya -including the counselor's communication skillsrelates to a righteous personality, the quality of the counselor's integrity. The therapeutic speech of a counselor also radiates from the quality of the counselor's transfer. 


\section{Conclusion}

Therapeutic speech principles in Al-Qur'an are: first, qaulan baligha is the speech of the verbal message conveyed by the communicator which must be good, sufficient (concise), and easy to understand. Communicators also pay attention to nonverbal languages (for example, kinesthetic, paralinguistic, proxemic, olfaction, and artifactual). If the verbal and nonverbal languages are fulfilled, then the messages will remain in the heart of the communicant. Second, qaulan ma'rufa is a good speech, honorable, under the politeness of society. Communicators also pay attention to non-verbal messages, the psychological condition of the communicant, and the sociological conditions of the surrounding community.

Third, the qaulan sadidan is true, correct, and enlightening speech. Fourth, qaulan kariman is the noble speech, contains the meaning of good, gentle, and full of kindness, forgiveness (generous) and respect words. Fifth, qaulan layyinan is a gentle and polite speech which is not containing a hate speech and must be supported by non-verbal messages. Sixth, the qaulan maysuran is the speech that triggers positivism and positive vibes.

These six therapeutic speech principles in the interpretation of Al-Mishbah can be applied in cyber-counseling. They are listening and attending skills, listening skills to counselees, and influential skills. Those are not only verbal messages but also non-verbal messages that must be balanced.

These therapeutic speech skills also come from the personal integrity of the counselor. These are not just looking at the contents of the messages (undur maa qala) but also who is the messenger (undur man qala). Thus, must be balanced between the good message and the personal quality of the messenger. Al-Qur'an-counseling communication skills based on the interpretation of Al-Qur'an should be a guideline for Muslim counselors in the practice of counseling.

\section{References}

[1] I. Muhsin, Tafsir Al-Qur'an dan Budaya Lokal. Jakarta: Balitbang Kemenag RI, 2010.

[2] M. Q. Shihab, Tafsir al-Mishbah: Pesan, Kesan dan Keserasian al-Qur'an, vol. 5. Jakarta: Lentera Hati, 2002.

[3] A. Nurdin, “Akar Komunikasi dalam Al-Qur'an,” J. Kaji. Komun., vol. 21, no. 12, p. 26, 2014.

[4] Muslimah, "Etika Komunikasi dalam Perspektif Islam," Sos. Budaya, vol. 13, no. 2, pp. 115-125, 2016.

[5] M. Zahid, "Komunikasi Santun dalam Al-Qur'an," Karsa, vol. 21, no. 2, pp. 175-197, 2013.

[6] A. Ariani, "Etika Komunikasi Dakwah Menurut Al-Qur'an," Alhadharah, vol. 11, no. 21, pp. 7-16, 2012.

[7] A. Mudlofir, "Pendidikan Karakter Melalui Penanaman Etika Berkomunikasi dalam Al-Qur'an," J. Islam., vol. 5, no. 2, pp. 367-382, 2011.

[8] A. Rachman and M. A. Setiawan, "Keterampilan Komunikasi Konseling Berbasis Ayat Al-Qur'an dalam Layanan Konseling Sufistik," Konseling Reli., vol. 8, no. 1, pp. $23-44,2017$.

[9] B. Shetzer and S. . Stone, Fundamentals of Guidence. Boston: Hougton Mifflin Company, 1981.

[10] J. McLeod, An Introduction to Counselling Third Editionx. New York: Open University Press, 2003.

[11] N. Hidayah, "Evaluasi Pelaksanaan Pelayanan Konseling di SMP se-Kota Malang 
( Laporan Penelitian)," Malang, 2008.

[12] N. Hidayah, "Cyber-Counseling Kognitif Behavioral: Peluang Konselor Berdaya Saing di Era MEA. Pidato pengukuhan Guru Besar Bimbingan dan Konseling." Universitas Negeri Malang, Malang, 2015.

[13] J. W. Bloom, J.W, and G. R. Waltz, Cyber counseling and Cyberlearning: An Ancore. Greensboro: CAPS Press, 2004.

[14] K. Goss and K. Anthony, Technology in Counselling and Psychotherapy:A Practitioner's Guide. NY: Palgrave MacMillan, 2003.

[15] R. et al. Kraus, Online Counseling A Handbook for Mental HealthProfessionals. India: Elsevier Inc, 2011.

[16] G. H. Gadamer, Truth and Method, Translatio. News Yorks: Continuum, 2004.

[17] A. Mappiare, Tipe-tipe Metode Riset Kualitatif: Untuk Eksplanasi Sosial Budaya dan Bimbingan dan Konseling. Malang: Elang Emas Bersama Prodi Bimbingan dan Konseling, 2013.

[18] Q. M. Shihab, Tafsir Al-Mishbah: Pesan, Kesan, dan Keserasian al-Qur'an, 2nd ed. Jakarta: Lentera Hati, 2012.

[19] K. Tudor and M. P. Worrall, Person-Centered Therapy. London: Roundledge, 2006.

[20] C. R. Rogers, Counseling and Psychotherapy Newer Concepts in Practice. Cambridge: The Ribersibe Press, 1942.

[21] G. Corey, Theory and Practice of Counseling and Psychotheraphy, 8th ed. Belmont: Thomson Higher Education, 2009.

[22] E. 1. Mennuti, Cognitive-Behavioral Interventions in Educational Settings: a Handbook for Practice. News York: Routledge, 2006.

[23] S. Arifn, Sang Pelopor: Kisah Tiga Kiai dalam Mengelola Bekas Bajingan. Surabaya: Pena Salsabila, 2014.

[24] S. Arifin, "Pengembangan Desain Konseling Berbasis Pesantren dengan Pendekatan Service-Learning," J. Bimbing. dan Konseling Islam, vol. 8, no. 2, pp. 110-132, 2018.

[25] D. Mulyana, Ilmu Komunikasi Suatu Pengantar. Bandung: Rosda, 2002.

[26] A. E. E. al. Ivey, Intentional Interviewing and Counseling: Facilitating Client Development in a Multicultural Society, 7th ed. Belmont: Brooks, 2010.

[27] S. Haberstroh and T. Duffey, "Face-to-face supervision of onlinecounselors: Supervisor perspectives," 2011.

[28] E. Mishna, E, "Cyber Counseling: Illuminating Benefits and Challenges," Clin Soc Work $J$, vol. 43, pp. 169-178, 2015.

[29] R. Williams, M. Bambling, and Q. Abbott, "In-session processes in online counselling with young people: An exploratory approach," Couns. Psychother. Res., vol. 9, no. 2, pp. 93-100, 2004.

[30] M. Q. Shihab, Tafsir Al-Mishbah: Pesan, Kesan, dan Keserasian al-Qur'an0. Jakarta: Lentera Hat, 2012.

[31] S. Arifin, "Komunikasi Kiai Pesantren: Pemberdayaan Komunitas Bajingan Perspektif Komunikasi Konseling," in 2nd Proceedings Annual Conference for Muslim Scholars, 2018.

[1] I. Muhsin, Tafsir Al-Qur'an dan Budaya Lokal. Jakarta: Balitbang Kemenag RI, 2010.

[2] M. Q. Shihab, Tafsir al-Mishbah: Pesan, Kesan dan Keserasian al-Qur'an, vol. 5. Jakarta: Lentera Hati, 2002.

[3] A. Nurdin, “Akar Komunikasi dalam Al-Qur'an,” J. Kaji. Komun., vol. 21, no. 12, p. 26, 2014. 
[4] Muslimah, "Etika Komunikasi dalam Perspektif Islam,” Sos. Budaya, vol. 13, no. 2, pp. 115-125, 2016.

[5] M. Zahid, "Komunikasi Santun dalam Al-Qur'an,” Karsa, vol. 21, no. 2, pp. 175-197, 2013.

[6] A. Ariani, "Etika Komunikasi Dakwah Menurut Al-Qur'an," Alhadharah, vol. 11, no. 21, pp. 7-16, 2012.

[7] A. Mudlofir, "Pendidikan Karakter Melalui Penanaman Etika Berkomunikasi dalam Al-Qur'an,” J. Islam., vol. 5, no. 2, pp. 367-382, 2011.

[8] A. Rachman and M. A. Setiawan, "Keterampilan Komunikasi Konseling Berbasis Ayat Al-Qur'an dalam Layanan Konseling Sufistik," Konseling Reli., vol. 8, no. 1, pp. 23-44, 2017.

[9] B. Shetzer and S. . Stone, Fundamentals of Guidence. Boston: Hougton Mifflin Company, 1981.

[10] J. McLeod, An Introduction to Counselling Third Editionx. New York: Open University Press, 2003.

[11] N. Hidayah, "Evaluasi Pelaksanaan Pelayanan Konseling di SMP se-Kota Malang ( Laporan Penelitian)," Malang, 2008.

[12] N. Hidayah, "Cyber-Counseling Kognitif Behavioral: Peluang Konselor Berdaya Saing di Era MEA. Pidato pengukuhan Guru Besar Bimbingan dan Konseling." Universitas Negeri Malang, Malang, 2015.

[13] J. W. Bloom, J.W, and G. R. Waltz, Cyber counseling and Cyberlearning: An Ancore. Greensboro: CAPS Press, 2004.

[14] K. Goss and K. Anthony, Technology in Counselling and Psychotherapy:A Practitioner's Guide. NY: Palgrave MacMillan, 2003.

[15] R. et al. Kraus, Online Counseling A Handbook for Mental HealthProfessionals. India: Elsevier Inc, 2011.

[16] G. H. Gadamer, Truth and Method, Translatio. News Yorks: Continuum, 2004.

[17] A. Mappiare, Tipe-tipe Metode Riset Kualitatif: Untuk Eksplanasi Sosial Budaya dan Bimbingan dan Konseling. Malang: Elang Emas Bersama Prodi Bimbingan dan Konseling, 2013.

[18] Q. M. Shihab, Tafsir Al-Mishbah: Pesan, Kesan, dan Keserasian al-Qur'an, 2nd ed. Jakarta: Lentera Hati, 2012.

[19] K. Tudor and M. P. Worrall, Person-Centered Therapy. London: Roundledge, 2006.

[20] C. R. Rogers, Counseling and Psychotherapy Newer Concepts in Practice. Cambridge: The Ribersibe Press, 1942.

[21] G. Corey, Theory and Practice of Counseling and Psychotheraphy, 8th ed. Belmont: Thomson Higher Education, 2009.

[22] E. 1. Mennuti, Cognitive-Behavioral Interventions in Educational Settings: a Handbook for Practice. News York: Routledge, 2006.

[23] S. Arifn, Sang Pelopor: Kisah Tiga Kiai dalam Mengelola Bekas Bajingan. Surabaya: Pena Salsabila, 2014.

[24] S. Arifin, "Pengembangan Desain Konseling Berbasis Pesantren dengan Pendekatan Service-Learning," J. Bimbing. dan Konseling Islam, vol. 8, no. 2, pp. 110-132, 2018.

[25] D. Mulyana, Ilmu Komunikasi Suatu Pengantar. Bandung: Rosda, 2002.

[26] A. E. E. al. Ivey, Intentional Interviewing and Counseling: Facilitating Client Development in a Multicultural Society, 7th ed. Belmont: Brooks, 2010.

[27] S. Haberstroh and T. Duffey, "Face-to-face supervision of onlinecounselors: Supervisor perspectives," 2011. 
[28] E. Mishna, E, "Cyber Counseling: Illuminating Benefits and Challenges," Clin Soc Work J, vol. 43, pp. 169-178, 2015.

[29] R. Williams, M. Bambling, and Q. Abbott, "In-session processes in online counselling with young people: An exploratory approach," Couns. Psychother. Res., vol. 9, no. 2, pp. 93-100, 2004.

[30] M. Q. Shihab, Tafsir Al-Mishbah: Pesan, Kesan, dan Keserasian al-Qur'an0. Jakarta: Lentera Hat, 2012.

[31] S. Arifin, "Komunikasi Kiai Pesantren: Pemberdayaan Komunitas Bajingan Perspektif Komunikasi Konseling," in 2nd Proceedings Annual Conference for Muslim Scholars, 2018. 